\title{
Nursing ethical processes in the State of Santa Catarina: characterization of factual elements
}

\author{
Dulcinéia Ghizoni Schneider ${ }^{1}$ \\ Flávia Regina Souza Ramos²
}

Objective: The present study aimed to characterize the processes of ethical and professional nursing transacted at the Regional Nursing Council of Santa Catarina (Coren/ $\mathrm{SC}$ ), considering their factual elements (events/offenses, causes and outcomes). Method: This descriptive, exploratory and documentary research with a quantitative approach was developed at Coren/SC. Data was collected from 128 professional ethical processes in nursing, between 1999 and 2007, analyzed descriptively with regard to the origin of the complaints and ethical processes, the denouncers, the accused, the subject of the complaint and the outcome of the process. Results: Considering the topics, out of the eight categories described, iatrogenesis was highlighted, as well as illegal professional practice, conflicting inter-professional relationships and professional responsibility of the nurse. Conclusion: The results show the need for discussion and intervention in concrete practical and arouse reflections about the process of professional training and continuous education in the institutional spaces of health, in order to reduce ethical occurrences in professional practice. Descriptors: Nursing Ethics; Organizations of Professional Normalization; Ethics Codes; Professional Responsibility.

\footnotetext{
${ }^{1}$ PhD, Professor, Universidade do Sul de Santa Catarina, Brazil.

2 PhD, Professor, Universidade Federal de Santa Catarina, Brazil.
} 


\section{Processos éticos de enfermagem no Estado de Santa Catarina: caracterização de elementos fáticos}

Objetivos: o objetivo deste estudo foi caracterizar os processos ético-profissionais de enfermagem, tramitados no Conselho Regional de Enfermagem de Santa Catarina (Coren/ SC), em seus elementos fáticos (ocorrências/infrações, causas e desfechos). Método: com desenho exploratório-descritivo e documental e abordagem quantitativa, este estudo foi desenvolvido nas dependências do Coren/SC. Os dados foram coletados em 128 processos ético-profissionais de enfermagem, no período de 1999 a 2007, e analisados descritivamente quanto à origem das denúncias e processos éticos, aos denunciantes, aos denunciados, ao tema da denúncia e ao desfecho do processo. Resultados: quanto aos temas, das oito categorias descritas, destacaram-se as iatrogenias, o exercício ilegal de profissões, as relações interprofissionais conflitantes e a responsabilidade profissional do enfermeiro. Conclusões: os resultados mostram a necessidade de discussão e intervenção nos problemas concretos da prática e suscitam reflexões sobre o processo de formação profissional e a continuidade dessa formação nos espaços institucionais de saúde, para reduzir as ocorrências éticas na prática profissional.

Descritores: Ética em Enfermagem; Organizações de Normalização Profissional; Códigos de Ética; Responsabilidade Profissional.

\section{Procesos éticos de la enfermería en la Provincia de Santa Catarina: caracterización de los elementos fácticos}

Objetivo: Este estudio tuvo como objetivo caracterizar procesos éticos-profesionales de la enfermería y tramitados en el Consejo Regional de Enfermería de Santa Catarina (COREN/SC), en sus elementos fácticos (acontecimientos/infracciones, causas y desenlaces). Método: Con un dibujo exploratorio-descriptivo, documental y de abordaje cuantitativo fue desarrollado en las dependencias del COREN/SC. Los datos fueron obtenidos en 128 procesos éticos-profesionales de enfermería entre 1999 y 2007, y fueron analizados descriptivamente en relación al origen de las denuncias y procesos éticos, a los denunciantes, a los denunciados, al tema de la denuncia y al desenlace del proceso. Resultados: Con relación a los temas, de las ocho categorías descriptas, se destacaron las iatrogenias, el ejercicio ilegal de profesiones, las relaciones interprofesionales conflictivas y la responsabilidad profesional del enfermero. Conclusión: Los resultados muestran la necesidad de discutir e intervenir en los problemas concretos de la práctica, suscita reflexiones sobre el proceso de formación profesional y la continuidad de esta formación en los espacios institucionales de la salud, para reducir las ocurrencias éticas en la práctica profesional.

Descriptores: Ética en Enfermería; Organizaciones de Normalización Profesional; Códigos de Ética; Responsabilidad Profesional.

\section{Introduction}

The discussion about solutions for ethical conflicts in care practice entail the need to study, identify and characterize these conflicts, highlighting the most frequent types, how decisions are made and how decision-making interferes for all stakeholders and for the profession's expression in society.

In daily Nursing practice, we are confronted with situations in which professionals have to choose 
between two or more equally desirable or undesirable alternatives. This demands reflection, discussion and ponderation, considering specific knowledge, values, ethical and legal principles and aggregated standards or rules of conduct. In health work, decisions imply interventions, involving other human beings who are often in weak or vulnerable situations. Then, the ethical contents of care are also problematized and should be addressed in this kind of analysis.

In that sense, this approach goes beyond the specialized conception of care, limited to technically competent action, towards the commitment to selfcriticism and a philosophy that can raise discussions on professional care ${ }^{(1)}$.

Besides technical preparation and constant recycling, nursing professionals need ethical commitment to reduce harmful events for patients* to a minimum and, therefore, managing risk situations in nursing care is fundamental(2). In that sense, nursing professionals need to know the ethical, professional, civil and penal responsibilities of their actions, as well as their rights and duties, in order to avoid negligence, incompetence or imprudence events.

Professional accountability is included in the rules or laws that guide professional practice and the ethics code of the respective profession(3). Responsibility is defined as the "possibility to foresee the effects of one's own behavior and correct it based on this prevision"(4). Professionals need to know their code of ethics and legislation ruling their profession, under penalty of not previewing the consequences of their actions.

The law guiding professional nursing practice is No. 7.489, issued on June $25^{\text {th }} 1986^{(5)}$ and regulated by Decree No. 94.406, issued on June $8^{\text {th }} 1987^{(6)}$. The Ethics Code of Nursing Professionals (CEPE), then, considers the population's need and right to nursing care, as well as the interests of professionals and their organization. The CEPE is centered on the person, family and group and presupposes that nursing workers are allied with users in the fight for risk and damage-free care that is accessible to the entire population ${ }^{(7)}$. The existence of an organization to watch over practical compliance with professional ethics is also fundamental, with educative actions and serving as a reference in situations that involve ethical conflicts. To respond to these needs, the Nursing Ethics Committees (NEC) emerged, in accordance with COFEN Resolution 172/94(8).
The aim of the Nursing Ethics Committee (NEC) is to guarantee Nursing professionals' ethical conduct at the institution; watch over Nursing professionals' ethical practice at the institution, fighting illegal professional practice, educating, discussing and disseminating the NEC; notify the Regional Nursing Council in its jurisdiction about irregularities, demands, suggestions and ethical infractions ${ }^{(8)}$.

The discussion on an ethical incident in Nursing can take place among the person who provoked it, the person who was affected and the responsible for the team. The institution's Nursing Ethics Commission can also evaluate the discussion, resulting in educative action to avoid new incidents or being forwarded to the Regional Nursing Council (Coren) as an accusation. The accusation can evolve to the establishment of an ethical process, in case of signs of ethical infractions.

In CEPE Chapter V, Art. 13 of Cofen Resolution $311 / 2007$, "Ethical infraction is considered as the action, omission or connivance that implies disobedience or inobservance of the determinations of the Ethics Code of Nursing Professionals"(7). Ethical Accusation is defined as the formal communication of a situation in which the professional activities of Nurses, Nursing Technicians and Auxiliary Nurses do not comply with the Law of Professional practice and/or with the CEPE, filed by a nursing professional, client/patient, family, health institution, ethics committee or any other stakeholder ${ }^{(9)}$. Despite these definitions, the ability of a code to cover the full range of such a complex practice should be questioned, despite frequent revisions, as they are always situated in a temporary or transitory context.

In this study, factual elements were defined as the facts described and necessary for the process to continue, which are: incidents/infractions, causes and outcomes. Ethical incidents are the facts that caused harm or loss to another person, as a result of a professional's attitude or action, and which can be characterized as a type of infringement on the code of ethics. The outcome is the final result of the process, the finishing determination, representing the alternative that is considered the most appropriate in the circumstances.

In view of the above, the following research question was established: what factual elements existed in the ethical processes concluded and analyzed at Coren-SC between 1999 and 2007? Thus, the aim in this paper is to analyze the factual elements present in

\footnotetext{
* In this study, the term "patient" was chosen because it appeared more frequently in the ethical-professional processes analyzed in the files of the Santa Catarina Regional Nursing Council (Coren/SC).
} 
the ethical processes concluded and filed at Coren-SC between 1999 and 2007.

\section{Method}

A quantitative study with an exploratory, descriptive and documentary design was accomplished. This excerpt is part of a doctoral dissertation* and explores quantitative data, collected directly from the organization's files, without removing documents and through the signing of the Data Use Commitment Term. In total, 200 hours of consultations took place between June and October 2009. Due to the lack of a computerized data base for consultation (which is the case in some Professional Councils or Civil and Penal Courts), in this case, the principles of the Brazilian Bar Association - $O A B^{(10)}$ were applied, considering that a disciplinary ethical process is secret while in course (principle of secrecy of investigation), but enter the public domain after the final decision (principle of dissemination of achieved results), so that ongoing processes were not analyzed. The choice of the time period is due to the fact that the ethical processes made available in the organization's files start in 1999 and that all processes for 2007 had been closed off.
The project received approval from the Ethics Committee for Research involving Human Beings (CEPSH) at Universidade Federal de Santa Catarina (UFSC), under Protocol No. 141/09 FR- 261865. In total, 208 accusations and 128 concluded ethical-professional processes were considered. For data collection, a script was used, applied to all documents referred to above, which contained: date; incident or theme of the accusation; the defendant's professional category; the denouncer (preserving his identity and only identifying the professional category, whether he is a client, relative or other person); the place of the incident (only the type of service, without identifying the name of the Institution); and the conclusion or forwarding. Data were grouped and theme categories were defined, typed in Excel and analyzed in EpiInfo 6.04 software, using descriptive statistics.

\section{Results}

As for the denouncers, besides people for whom presenting accusations is part of their office or representative role, nurses stand out, followed by the Nursing Ethics Committees (NEC) at the institutions where the incident took place, auxiliary nurses and physicians (Figure 1).

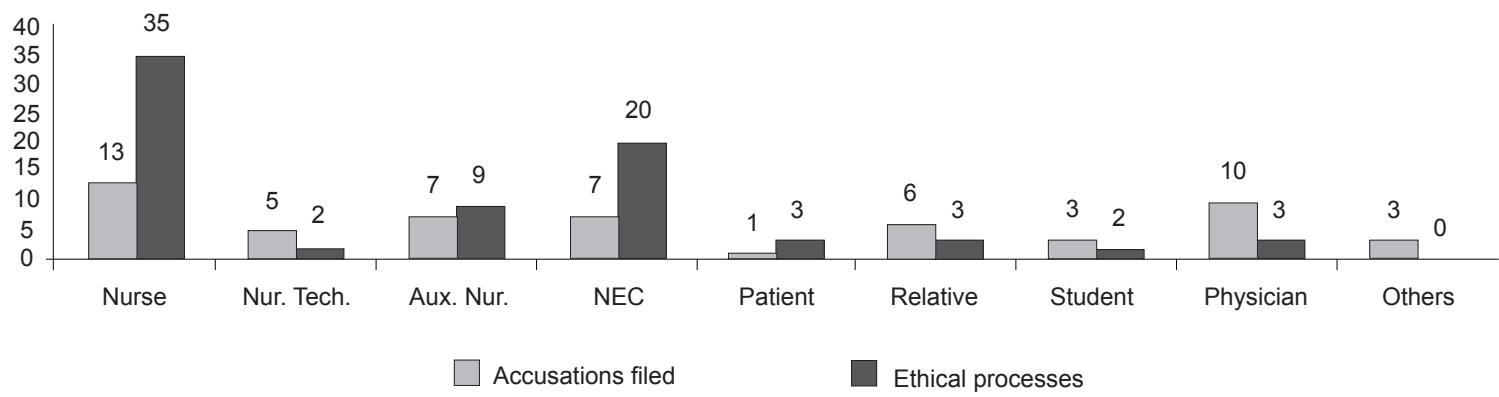

Figure 1 - Denouncers in accusations files and ethical processes - Coren/SC, Brazil, 1999-2007(11)

In the following table, accusation categories are presented, considering both rejected accusations and terminated ethical processes. Because of the ethical processes' incident date, Nursing Attendants still existed as a category.

Table 1 - Rejected accusations and concluded ethical processes (Coren/SC- Brazil, 1999-2007), per accusation category(11)

\begin{tabular}{lccc}
\hline & Category & Rejected accusation & Ethical process \\
\hline Nurse & 64 & 61 & Total \\
Nursing Technician & 04 & 36 & 125 \\
Auxiliary Nurse & 20 & 66 & 07 \\
Nursing Attendant & 01 & 02 & 08 \\
Midwife & - & 05 & 05 \\
Nursing Team & 05 & 05
\end{tabular}

* Schneider DG. Discursos profissionais e deliberação moral: análise a partir de processos éticos de enfermagem [doctoral dissertation]. Florianópolis (SC) Graduate Nursing Program at Universidade Federal de Santa Catarina; 2010. Winner of the Capes Thesis Award 2011. 
Considering the theme of the accusation, the ethical processes were organized in 26 themes, grouped in 08 categories, which are: iatrogenic cases, illegal professional practice, interprofessional relations, responsibility of the nurse, patient aggression and mistreatment, diverse crimes, negligence, professional policy and image. The total number of incidents (158) is higher than the number of ethical processes under analysis (128) because some processes included more than one incident (Table 2).

Table 2 - Accusations and ethical processes (Coren/SC - Brazil, 1999-2007), per theme or motive(11)

\begin{tabular}{|c|c|c|c|c|}
\hline Category & Accusation/Process Theme & No & Total & $f(\%)$ \\
\hline \multirow[t]{2}{*}{ latrogenic cases } & 1. latrogenic cases associated with imprudence, incompetence or negligence & 19 & & \\
\hline & $\begin{array}{l}\text { 2. Medication-related iatrogenic cases associated with imprudence, } \\
\text { incompetence or negligence }\end{array}$ & 15 & 34 & 21.5 \\
\hline \multirow[t]{3}{*}{ Illegal professional practice } & 3. Illegal practice of medicine & 16 & & \\
\hline & 4. Illegal practice of the profession of Nurse & 14 & 33 & 20.9 \\
\hline & 5. Illegal practice of the profession of Nursing Technician or Auxiliary Nurse & 03 & & \\
\hline \multirow[t]{7}{*}{ Interprofessional relations } & 6. Relations: moral harassment & 12 & & \\
\hline & 7. Relations: limits and confrontation between competences & 05 & & \\
\hline & 8. Relations: power abuse & 05 & & \\
\hline & 9. Relations: verbal aggression & 02 & 28 & 17.7 \\
\hline & 10. Relations: physical aggression & 02 & & \\
\hline & 11. Relations: insubordination & 01 & & \\
\hline & 12. Relations: mistreatment & 01 & & \\
\hline Responsibility of the Nurse & 13. Responsibility of the Nurse & 22 & 22 & 14.0 \\
\hline \multirow[t]{2}{*}{ Aggression and mistreatment } & 14. Verbal aggression of patient & 07 & 13 & 82 \\
\hline & 15. Patient mistreatment & 06 & 10 & 0.2 \\
\hline \multirow[t]{7}{*}{ Diverse crimes } & 16. Embezzlement of psychotropic drugs & 05 & & \\
\hline & 17. Fraud in patient files & 03 & & \\
\hline & 18. Baby traffic & 01 & & \\
\hline & 19. Abortion & 01 & 13 & 8.2 \\
\hline & 20. Plagiarism & 01 & & \\
\hline & 21. Sexual harassment of patient & 01 & & \\
\hline & 22. Sexual harassment of companion & 01 & & \\
\hline Negligence & 23. Negligence & 11 & 11 & 7.0 \\
\hline \multirow[t]{3}{*}{ Professional policy and image } & 24. Professional policy & 01 & & \\
\hline & 25. Financial professional policy & 02 & 04 & 2.5 \\
\hline & 26. Nurse degree unproved & 01 & & \\
\hline Total & & & 158 & 100 \\
\hline
\end{tabular}

What the forwarding/outcome of the process is concerned, some resulted in more than one penalty, so that 149 outcomes represent the final result of the process, the concluding deliberation and the alternative that was considered most appropriate for the circumstances (Table 3).

Table 3 - Outcome of the ethical process (Coren/SC - Brazil, 1999-2007), according to application of penalties ${ }^{(11)}$

\begin{tabular}{lcc}
\hline \multicolumn{1}{c}{ Outcome - Penalty } & Total & Frequency (\%) \\
\hline Filing & 56 & 37.5 \\
Absolution & 69 & 29.1 \\
Verbal warning & 44 & 15.4 \\
Reprimand & 23 & 6.1 \\
Fine & 09 & 4.1 \\
Suspension of professional practice for up to 29 days & 06 & 1.3 \\
Disfranchisement of the right to professional practice & 02 & 100 \\
Total & 149 \\
\hline
\end{tabular}




\section{Discussion}

In the item related to the denouncers, as illustrated in Figure 1, it is important to highlight that the nurses and NEC's accusations mostly resulted in ethical processes, which may be related to the nurse's task as a coordinator and supervisor of nursing care. The NECs receive several accusations, verify the facts preliminarily, collect testimonies and issue an opinion, which is forwarded to the Coren President when necessary. In other situations, the NECs merely report the facts and the collected testimonies.

The number of patients and relatives who made accusations was small, possibly due to a reality in which the lack of information on users' rights and duties and on the channels for this type of manifestation still persists, or to the silence imposed by asymmetric relations and fear of retaliations during other occasions of health care delivery.

Among the categories of defendants (Table 1), Nurses receive most accusations, underlining the shared responsibility as a result of these professionals' competency, in line with Law $7.498 / 86$ of professional Nursing practice ${ }^{(5)}$. In other cases, the accusation followed upon the permission to let unskilled people perform nursing activities, characterizing illegal practice of the profession of nursing technician and auxiliary nurse. This is implied in the action of the Federal Council/Regional Councils system to protect society against people who are unskilled to practice Nursing and, consequently, against the risk and possible damage deriving from these actions.

Accusations against nursing attendants and midwifes were limited to 1999 and 2000, when remnants of the professionalization process in SC still remained. It is highlighted that accusations against the "nursing team" were rejected and filed because of insufficient evidence or difficulties to name the persons involved.

Some accusations related to conflicting relations led to in loco verification, allowing the Surveillance Service to identify irregularities, commonly related to the illegal practice of the profession of auxiliary nurse or nursing technician. The Coren president, in office, provides for an ethical process against illegal practitioners, and also against the nurse who is the technical responsible for the nursing service at the institution in question.

The themes of the accusations that led to the ethical processes (Table 2) show iatrogenic events as the motivation for $34(21.5 \%)$ incidents; both medication (15 cases) and non-medication related events (19 cases) were associated with imprudence, incompetence or negligence. The term iatrogenic refers to "the negative or harmful aspects of the influence the physician and his behavior exert on treatment"(12). The expansion of nursing's own knowledge and specific and interdependent actions expose Nursing to the same risk as the medical category ${ }^{(13)}$. Hence, iatrogenic events in nursing care refer to the privation of this care, its imposition or unsatisfactory delivery, which determines some disorder, damage or harm to the patient's wellbeing(13).

Iatrogenic events can be considered ethical incidents, adverse events, negative critical incidents and errors, due to risks caused by procedures and bad information interpretation, related to imprudence or incompetence; omission or negligence, in case of bad assessment of the potential risk an action entails ${ }^{(14)}$.

The administration of a drug the physician had not prescribed, i.e. unintentional medication exchange; wrong administration route or dose stand out as errors associated with professionals' lack of care and knowledge.

Brazilian law accepted the principle of inexcusability, which means that alleging lack of knowledge is not a pretext to disregard standards and laws(3). As opposed to denying the benefits of care, the study of iatrogenic incidents has contributed to work towards the continuous improvement of nursing service quality, in an inseparable pair: the safety of who delivers care and who receives care ${ }^{(15)}$. The terms technical failure, related to technical or procedure errors, and conduct failure, characterized by errors in one's attitude, behavior, interpersonal or interprofessional approach, can be expressed in the discussion of iatrogenic events and in establishing the concepts of ethical-legal infractions that cause patient harm(16). Therefore, permanent education is a fundamental instrument for personal qualification and development, through technical training and the acquisition of new knowledge and concepts, which should be translated into attitudes, closely related with the education and work process ${ }^{(17)}$.

Illegal practice of the profession of physician, nurse, nursing technician or auxiliary nurse resulted in $33(20.9 \%)$ accusations. These were mostly related to the administration of non-prescribed medication and the issuing of bills of health; to the coordination of the nursing service by nursing technicians or auxiliaries; and to unskilled persons working as nursing technicians and auxiliary nurses.

Illegal practice of the profession or activity is a crime included in the Misdemeanor Criminal Law, which determines in Art. 47 that one cannot exercise 
a profession or economic activity or announce that one does so without fulfilling the conditions its practice is subordinated to by law, being subject to the established penalty ${ }^{(3)}$. It should be highlighted that the Law of Professional Nursing Practice highlights that elementary Nursing activities can only be performed under the orientation and supervision of the nurse and also emphasizes the transitory nature of the Nursing Attendant function, a category extinct in the state.

Another important set of accusations, with 28 incidents $(17.7 \%)$, was related to nursing professionals' conflicting relations, both mutually and with the health team, mostly motivated by moral harassment, confronting competences and power abuse. Most of these processes, involving nurses, were filed due to a lack of materiality, suggesting personal conflicts. The term moral harassment refers to any abusive conduct through words, actions or behaviors that can infringe on the worker's physical or mental integrity ${ }^{(18)}$. Its physical and emotional consequences interfere in the person's quality of life, in the work environment as well as in his/ her personal life.

The nurse's ethical professional responsibility, evidenced in $22(14.0 \%)$ accusations, was related with the permission for improperly qualified people to practice the profession, with the lack of supervision and orientation when technicians and auxiliaries perform activities. This remits to the notion of professional responsibility that emerges from the relation between the violation of a legal duty, the inobservance of the premises described in ethics codes and other standards that regulate the profession ${ }^{(3)}$.

Nurses should be trained to act with a sense of social responsibility and commitment to citizenship, as a promoter of human beings' holistic health. Moreover, they should possess the knowledge required to practice general competences and skills for health care, decision making, communication, leadership, administration and management and permanent education ${ }^{(19)}$. Hence, many accusations against nurses occurred because of shared or solidary responsibility in nursing care, considering that Article 38 of the CEPE, about responsibilities and duties, states "Assuming the responsibility for an error committed in one's professional activities, independently of having been practiced individually or as a team"(7).

Verbal aggression and mistreatment of patients were the motives for accusations in 13 (8.2\%) ethical processes, demonstrating asymmetric and authoritarian relations between the nursing professional and the patient and family. Many of the inequalities in this relation do not only represent differences, but relations between unequal forces, with moral implications, which highlights the importance of communication to reduce these asymmetries(20). In most of these accusations, the defendants were auxiliary nurses and nursing technicians, demanding an analysis of the reasons involved in this frequency and possible relations with these professionals' work conditions and ethical preparation.

Another 13 (8.2\%) accusations corresponded to diverse crimes, including the embezzlement of psychotropic drugs, mainly for own use; fraud against the Unified Health System (completion of data in the file after hospital discharge); falsification of nursing records; sexual harassment of the patient and companion; and, in single cases, plagiarism, participation of a nursing professional in baby traffic and abortion. Crime is a fact prohibited by law, whose occurrence entails a penalty, established for the sake of the social security of the state and the benefit of the group(21). Although the category included infractions with different levels of severity, it joined incidents that went beyond ethical premises and involved criminal responsibility, without excluding crimes grouped in other categories.

Accusations of negligence, present in 11 (7.0\%) processes, are characterized as acts of omission, not doing a necessary act for care. Negligence harms the patient and can result from the professional's lack of interest, but can also derive from fatigue and an excessive activity burden, as a result of the inadequate work conditions imposed on many nursing professionals in health institutions ${ }^{(22)}$

Four accusations $(2.5 \%)$ were characterized as professional policy and image, especially related to debits to Coren/SC (2) and the incitement of nursing professionals against the Coren/SC during one term in office (1). All practicing professionals are obliged to register in their regional Coren and pay annual fees.

The final case in this category refers to an unproved degree or dissemination of a false image after a nursing technician announced the degree of nurse. Nursing professionals are mistakenly called nurses; bad faith occurs when technicians call themselves nurses to gain advantage.

Among the forwarding/outcomes of the ethical processes (Table 3), $37.5 \%$ were filed and $6.1 \%$ absolved because they did not characterize any ethicalprofessional infraction. In $29.5 \%$ of the processes, the penalty was a verbal warning, which involves a reserved admonition of the infractor, to be registered in his/her 
file, in the presence of two witnesses $^{(7)}$. In $15.4 \%$ of the processes, a reprimand was applied, characterized by a reprehension issued in official publications of the Federal and Regional Councils and newspapers. Fine, a penalty that involves the obligatory payment of one to ten times the annual fee for the professional category the infractor belongs to, was applied in $6.1 \%$ of the processes ${ }^{(7)}$.

Suspension is the prohibition to practice the Nursing profession for 29 days at most, disseminated in official publications by the Federal and Regional Councils and newspapers and communicated to employers ${ }^{(8)}$, applied in $4.1 \%$ of professional ethical processes. Disfranchisement of the right to professional practice, the penalty applied in $1.3 \%$, is the loss of one's right to practice the Nursing profession and is disseminated as described earlier(7).

\section{Conclusions}

Demonstrating the factual elements of ethical processes that took place in Coren-SC provided a view of the problem that can be similar to other states. In the study context, iatrogenic events stood out, as well as illegal professional practice, conflicting interpersonal relations and incidents related to nurses' professional accountability. These results are characterized as severe ethical problems that influence care quality, patient safety, work conditions and the image of the profession in society.

Nursing confirms the commitment to deliver care to human beings, as it exposes its weaknesses and, at the same time, its strengths when working with a wide range of subjects, care situations, technology and human and material resources. Daily practical conflicts, conflicting situations and dilemmas accompany professionals, considering that practical problems are not just technical, but also ethical, moral, social, economic and political.

The incidents under analysis remit to reflections about the professional education process and its continuity in the institutional health context, to the need to discuss the problems some professional and the profession as a whole have experienced.

Delivering care to human beings in situations of physical, emotional and social weakness is a complex activity and preparing for this activity should also cover different dimensions and responsibilities. Acknowledging one's limitations and seeking help could contribute to minimize errors, mainly related to iatrogenic events.

In this research, signs of how Nursing judges and establishes the judgment of its actions in practice for itself could be demonstrated. Being able to manage care risks is essential to put in practice one of the fundamental principles of the CEPE in the professional's commitment to health and quality of life. By presenting the present study results, we also intend to stimulate the interest in the creation of Nursing ethics committees in health institutions, with a view to guaranteeing a space for discussion and exemplary practices by nursing professionals.

\section{References}

1. Ramos FRS, Bertoncini JH, Machado RR, Flor RC, Pires DEP, Gelbcke FL. Trabalho, educação e política em seus nexos na produção bibliográfica sobre o cuidado. Texto Contexto Enferm 2009;18(2):361-8.

2. Freitas GF, Oguisso T. Ocorrências éticas com profissionais de enfermagem: um estudo quantitativo. Rev Esc Enferm USP. 2008;42(1):34-40.

3. Oguisso T, Schmidth MJ, Freitas GF. Fundamentos teóricos e jurídicos da profissão de enfermagem. Enfermagem em Foco. 2010;1(1):9-13.

4. Abbagnano N. Dicionário de filosofia. 4a ed. São Paulo: Martins Fontes; 2003.

5. Lei $7498 / 86$ de 25 de junho de 1986 (BR). Dispõe sobre a regulamentação do exercício da Enfermagem e dá outras providências. Diário Oficial da União [periódico na Internet]. 25 jun 1986. [acesso 15 dez 2009]. Disponível em: http://www.portalcofen.gov.br

6. Decreto 94.406 de 08 de junho de 1987 (BR). Regulamenta a Lei no 7.498, de 25 de junho de 1986, que dispõe sobre o exercício da enfermagem, e dá outras providências. Diário Oficial da União [periódico na Internet]. 08 jun 1987. [acesso 15 dez 2009]. Disponível em: http://www6.senado.gov.br/legislacao/ ListaPublicacoes.action?id $=131186$

7. Conselho Federal de Enfermagem (BR). Resolução COFEN 311/2007 de 08 de fevereiro de 2007. Aprova a Reformulação do Código de Ética dos Profissionais de Enfermagem. 08 fev 2007. [acesso 15 dez 2009]. Disponível em: http://www.portalcofen.gov.br/ Site $/ 2007 /$ materias. asp? ArticleID $=7221$ \&sectionID $=34$

8. Conselho Federal de Enfermagem (BR). Resolução COFEN 172/1994 de 15 de junho de 1994. Normatiza a criação de Comissão de Ética de Enfermagem nas instituições de saúde. 15 jun 1994. [acesso15 dez 2009]. Disponível em: http://site.portalcofen.gov.br/ node/4246

9. Pires DEP, Bellaguarda MLR, Zago AT, Matos E. Consolidação da legislação e ética profissional. 
Florianópolis: Conselho Regional de Enfermagem SC/ Quorum Comunicação; 2010.

10. Ordem dos Advogados do Brasil (BR). Resolução no 003/98 de 25 de janeiro de 1998. Dispõe sobre a criação da Coordenadoria das Comissões da OAB/SC, e define suas atribuições e competências. 25 jan 1998. [acesso 10 mai 2009]. Disponível em: http://www.oab-sc.org. $\mathrm{br} /$ setores/comissoes/regimento.jsp

11. Schneider DG. Discursos profissionais e deliberação moral: análise a partir de processos éticos de enfermagem [tese de doutorado]. Florianópolis (SC): Programa de Pós-Graduação em Enfermagem da Universidade Federal de Santa Catarina; 2010.

12. Maldonado de Carvalho JC. Iatrogenia e erro médico sob o enfoque da responsabilidade civil. 3a ed. Rio de Janeiro: Lumen Júris; 2009.

13. Madalosso ARM. Iatrogenia do cuidado de enfermagem: dialogando com o perigo no quotidiano profissional. Rev. Latino-Am. Enfermagem. 2000;8(3):11-7.

14. Vargas MAO, Ramos FRS. Iatrogenesis in Intensive Care Units: dramatization of Contemporary Bio/ Ethical Problems. Rev. Latino-Am. Enfermagem [periódico na Internet]. 2010 Out [acesso 30 jul 2012] ; 18(5): 990-997. Disponível em: http://www. scielo.br/scielo.php?script=sci_arttext\&pid=S0104$11692010000500021 \&$ Ing $=$ pt. http://dx.doi. org/10.1590/S0104-11692010000500021.

15. Padilha KG. Considerações sobre as ocorrências iatrogênicas na assistência à saúde: dificuldades inerentes ao estudo do tema. Rev Esc Enferm USP. 2001;35(3):287-90.

16. Vargas MAO, Ramos FRS. Iatrogenesis in Intensive Care Units: Dramatization of Contemporary Bio/ Ethical Problems. Rev. Latino-Am. Enfermagem. 2010;18(5):990-7.

17. Trevizan MA, Mendes IAC, Mazzo A, Ventura CAA. Investment in nursing human assets: education and minds of the future. Rev. Latino-Am. Enfermagem. 2010;18(3):467-71.

18. Thofehrn MB, Amestoy SC, Carvalho KK, Andrade FP, Milbrath VM. Assédio moral no trabalho da Enfermagem. Cogitare Enferm. 2008;13(4):597-601.

19. Conselho Nacional de Educação (BR). Resolução CNE/CES No 3 de 07 de novembro de 2001. Institui Diretrizes Curriculares Nacionais do Curso de Graduação em Enfermagem. Diário Oficial da União [periódico na Internet]. 07 nov 2001. [acesso 03 dez 2009]. Disponível em: http://portal.mec.gov.br/sesu/arquivos/ pdf/0301Enfermagem.pdf

20. Soares NV, Lunardi VL. Communication, the information as a possibility for reducing the asymmetry between the health professional and the client. In: Proceedings of the 8 . Brazilian Nursing Communication Symposium [Proceedings online]; 2002 May 0203; São Paulo, SP, Brazil. 2002 [acesso 30 jul 2012]. Disponível em: http://www.proceedings.scielo.br/scielo. php?script $=$ sci_arttext\&pid $=$ MSC000000005200200010 0027\&Ing=en\&nrm=van .

21. De Plácido S. Vocabulário jurídico conciso. Rio de Janeiro: Forense; 2008.

22. Grossi V Sobrinho, Carvalho EC. Uma visão jurídica do exercício profissional da equipe de enfermagem. Rev Enferm UERJ. 2004;12:102-8. 